\title{
Constraints in The Implementation of Problem-Based Learning in Subject of History in State Senior High School 2 Sendawar
}

\author{
Petronela Sherlly', Jamil'2, Muhamad Sopyan ${ }^{3}$ \\ ${ }^{1}$ History Education Department, Mulawarman University, Indonesia \\ ${ }^{2}$ History Education Department, Mulawarman University, Indonesia \\ ${ }^{3}$ History Education Department, Mulawarman University, Indonesia \\ 2jamil@fkip.unmul.ac.id, 3muhamad.sopyan@fkip.unmul.ac.id
}

\begin{tabular}{ccc}
\hline Received & Accepted & Published \\
$05 / 01 / 2018$ & $26 / 04 / 2018$ & $30 / 04 / 2018$ \\
\hline
\end{tabular}

Abstract This study aims to determine the application of historical learning model by using problem-based learning and obstacles from implementing problem-based learning model in history learning. This research uses descriptive qualitative research method. Data collection using observation and interview techniques. The result of the research shows that learning process is more centred on student activity with problem-solving related to history lesson material and obstacles in applying problem-based learning is the understanding and ability of educator in using learning model, complicated, limited time, facilities and infrastructure.

Keywords: Problem Based Learning; History Lesson; Sendawar.

Abstrak Penelitian ini bertujuan untuk mengetahui penerapan model pembelajaran sejarah dengan menggunakan pembelajaran yang berbasis masalah dan hambatan dari pengimplementasian model problem based learning dalam pembelajaran sejarah. Penelitian ini menggunakan metode penelitian deskriptif kualitatif. Pengumpulan datanya menggunakan teknik observasi dan wawancara. Hasil penelitian menunjukkan bahwa proses pembelajaran lebih berpusat pada aktivitas siswa dengan pemecahan masalah yang berkaitan dengan materi pelajaran sejarah dan hambatan dalam penerapan problem based learning adalah pemahaman dan kemampuan pendidik dalam menggunakan model pembelajaran, ribet, keterbatasan waktu, sarana dan prasarana.

Kata kunci : Problem Based Learning; Pembelajaran Sejarah; Sendawar. 


\section{INTRODUCTION}

The purpose of national education is to develop the potential of learners to become human beings who believe and piety to God Almighty, noble, healthy, skilful creative, and become citizens of a democratic and responsible. In connection with the above, the current problems in schooling are often considered unattractive, drowsy and boring. In the learning process, still dominated by conventional paradigm, that is paradigm "teacher explain-student listens".

This kind of learning model has made the lessons boring. Therefore, to solve various problems in learning, it is necessary to make renewed efforts in various fields as well as in the curriculum related to the learning model. As Joyce \& Calhoun, (2010) say that the learning model is a plan or a pattern that can be used to develop the curriculum. Thus, the learning model is very important to note for success in the learning process. Suyanto \& Jihad (2013) explain that the learning model is a conceptual framework that describes a systematic procedure in organizing the learning experience to be attained to achieve a particular goal. Thus, the learning method is a set of concepts that are expected to be able to arrange the curriculum in actualizing the learning experience systematically to achieve a goal. As in the learning objectives, existing in Bruner's learning and learning theories aim to provide the learning process and establish the optimal learning method Budiningsih (2005).

In theory, Behavioristic learning aims to change behaviour as a result of the interaction between stimulus and response. So in practice, this learning theory in learning is dependent on the purpose of learning, the nature of the subject matter, characteristics of students, media and learning facilities are available Aman (2011) Give learning process and set optimal learning method Budiningsih (2005).

Cognitive learning theory, focusing more on the learning process than learning result. While learning meaningful Ausubel which is a meaningful learning for students, so that in learning materials assimilated with the knowledge possessed with the knowledge that has been owned by students in the form of cognitive structure. Similarly, constructivism theory is the process of constructing knowledge through experience as a result of the interaction between learners and the reality of both personal realities, nature, and social reality Widyaningsih \& Yusuf (2015).

In relation to several theories in learning, the theory that is carried out in this study is constructivism theory, where the learning about history by using problem-based learning model that is adapted to the characteristics of certain mathematics.

Each course, of course, has distinctive characteristics, as well as with the subject of history. According to Aman (2011) characteristics of history subjects such as having: (1) heroic values, exemplary, pioneering, patriotism, nationalism, and unyielding spirit; (2) contains the 
treasures of the civilization of nations, including the Indonesian nation; (3) instilling awareness of unity and brotherhood and solidarity to become the glue of the nation is facing the threat of disintegration of the nation; (4) loaded with moral teachings and wisdom useful in overcoming multidimensional crisis faced in everyday life. To cultivate critical power problems in the learning process, of course, using a problem-based learning approach. Problem-based learning is based on the theory of learning Constructivism. In addition, the theory on which the problembased method of learning is based in the theory of Vygotsky's learning that social interaction with other friends triggers the formation of new ideas and enriches the intellectual development of students.

Problem-based learning is also based on the learning theory of Jerome S. Bruner which emphasizes that the method of discovery. This method is in line with the active search for knowledge by humans, by itself giving better results and will produce meaningful learning, as Dahar says in Rusman \& Pd (2012). Based on the description of problem-based learning from these experts, in learning history, students are required to obtain their own knowledge, and this knowledge is obtained by seeking information to solve problems related to the subject matter of history. As stated by Ibrahim and Nur in Rusman \& Pd (2012) explains that problem-based learning is one of the learning approaches used to stimulate the high-level thinking of students in situations oriented to real-world problems. Thus the problem-oriented learning method is problem-based learning because this learning is a learning approach that uses real-world problems as a context for learners to learn about critical thinking and problem-solving skills Eggen \& Kauchak (2007).

Similarly, Sugiyanto, Si, \& Si (2010) proposed that problem-based learning is a learning that presents an authentic and meaningful problem. Problem-based learning as Tan said in Suyanto \& Jihad (2013) is the use of the various intelligence needed to confront a challenge to the real world. This study aims to explain how the implementation of learning history in general along with various obstacles faced in applying the model of Problem Based Learning learning on the subjects of history in class XI IPS 3 SMA Negeri 2 Sendawar.

\section{METHOD}

The approach used in this research is a qualitative descriptive approach. This research was conducted in class XI IPS 3 SMA Negeri 2 Sendawar. The technique of collecting data in this research is using observation, interview and documentation. Data analysis techniques in this study using Miles and Huberman analysis techniques that are data reduction, data presentation, and verification/conclusion are done simultaneously. 


\section{RESULT AND DISCUSSION}

\section{Learning history using Problem Based Learning}

Model The learning model is a conceptual framework that describes the systematic procedure of organizing the learning experience to achieve a particular goal and serves as a guide for teachers in planning and implementing learning activities Winataputra in Suyanto \& Jihad (2013) The use of learning model should be the center of attention of teachers as educators in every teaching and learning activity. Therefore, teachers need to establish learning models that will be used in the learning process so as to facilitate the achievement of learning objectives to be achieved. In fact, however, learning models are often overlooked for reasons such as time constraints and complex ideas for preparing the necessary materials before using a particular model, teachers also teaching in other schools. Therefore, as educators must have the insight and skills in selecting and using learning models that can support in the learning process. One of the models that suit the characteristics of history learning is the Problem-Based Learning model as an appropriate model to support the success of learning. Based on the characteristics of Problem Based Learning as explained by Rusman \& Pd (2012) as follows: (1) problem becomes (starting point) in learning; (2) the problem raised is an unstructured realworld problem; (3) problems require multiple perspectives; (4) issues that challenge students' knowledge, attitudes and competencies that then require the identification of learning needs and new learning areas; (5) self-direction learning becomes the main thing; (6) the use of diverse knowledge resources, their use, and evaluation of information resources is an important process in Problem Based Learning; (7) Learning is collaborative, communication and cooperative; (8) Inquiri experience and problem-solving skills are as important as mastering the content of knowledge to find solutions to a problem; (9) process openness in Problem Based Learning includes synthesis and integration of learning process; (10) Problem Based Learning involves evaluating and reviewing students' experiences and learning processes.

Problem Based Learning Model in the process most students are more active in solving a problem in the group. The understanding of a teacher about the use of learning model to present the subject matter to be delivered to the students is very necessary, it is done because the learning model is the basic or the beginning of capital, where a teacher apply the strategy of mastery of the classroom situation and students while learning so that the model of learning Problem Based Learning as a very appropriate model used in teaching and learning process. Based on the interview with Lantik that learning history using Problem Based Learning is very well applied to the subjects of history because the use of this model resulted in students and less enthusiastic students become more active in the learning process and teachers can be helped in mastering the class situation. Furthermore, the use of Problem Based Learning model is quite effective for historical lessons on certain materials. But, not all historical material is appropriate 
for the Problem Based Learning model of learning. After I used this model, I saw students' progress in the classroom learning process increase so that they were more active in the learning process of history.

Based on the previous discussion that the use of Problem Based Learning model on learning history can provide motivation, student activeness during the learning process takes place.

\section{Obstacles to Implementation of Problem Based Learning Learning}

Learning is a deliberate effort to manage the learning environment in order for a person to form himself positively in certain circumstances, while teaching business guides and directing learning experiences to learners that usually take place in formal situations Yamin (2013) In the learning process the teacher should give the opportunity to the students to play an active role in seeking information, process information, conclude and then apply it by providing a learning environment that makes students not depressed and happy to do learning activities. In the process of learning history in SMA Negeri 2 Sendawar usually teachers use lectures and question and answer, teachers only explain the material presented and students record and understand the explanation opened by the teacher. So in the learning process, the teacher did not use the learning model. As the result of an interview with Bapak Lantik, that the process of studying history is usually done in class XI IPS by using lecture method, question and answer and I also use the method of discussion. Teachers rarely use the learning model in teaching history, it is because it takes a lot of time because of the material that needs to be prepared if using a particular learning model, and I also teach other schools so I use lecture methods, questions and answers.

The opinions of different history teachers, such as the results of interviews with Agung about how their feelings about the use of problem-based learning methods on the subject matter of history are good and appropriate because the subject of history becomes no longer neglected. In the process of learning, teachers are required to be able to master the classroom materials and situations and students must be active in the learning process. Historical learning process conducted in class XI IPS 3, found some students who are not serious in following the process of learning history by doing other activities such as leaning his head on the table, talking with his friends when teachers explain the material and so forth. Historical teachers need to develop in the process of learning history using methods, approaches, and learning models as a step in creating an interesting, varied learning history that can inspire students' learning spirit. Problems using Problem Based Learning model in history learning, as said by Lantik that it is not too difficult in using Problem Based Learning model. For him, each learning model has its advantages and disadvantages, including the model of Problem Based Learning. However, 
constraints not all historical material can be applied to the Problem Based Learning model, this learning model takes a lot of time to prepare.

Based on the results of research and discussion related to obstacles faced by teachers in using problem-based learning (PBL) method is initially Teachers do not use PBL model in history learning process, this is because teachers believe time limitations in using PBL model, the use of PBL model also will have a complex effect because many materials need to be prepared, otherwise not all historical subjects can apply this method. However, after using problem based learning in the learning of history then the attitude of learners follow the learning process and not doing activities such as playing Mobile, talking with friends, leaning on the table, reflecting, In addition the learners are able to present the work of the group and answer questions raised by other groups.

\section{CONCLUSION}

Based on the explanation of the results and discussion it can be concluded as follows: Problem Based Learning model causes the learning process is more centred on student activity with problem-solving related to the subject matter of history so as to create a fun learning. However, the obstacles faced by the history teacher while teaching using the Problem Based Learning model is that teachers usually teach using lecture methods, time constraints, teachers' understanding using the learning model is still low, the limited facilities and infrastructure available in schools and so forth

\section{REFERENCES}

Aman. (2011). Model Evaluasi Pembelajaran Sejarah. Yogyakarta: Penerbit Ombak.

Eggen, P. D., \& Kauchak, D. P. (2007). Educational psychology: Windows on classrooms. Prentice Hall.

Joyce, B., \& Calhoun, E. (2010). Models of professional development: A celebration of educators. Corwin Press.

Rusman, D., \& Pd, M. (2012). Model-Model Pembelajaran. Raja Grafindo, Jakarta.

Sugiyanto, H., Si, M., \& Si, M. (2010). Model-model Pembelajaran inovatif. Surakarta: Yuma Pressindo.

Suyanto \& Jihad, A. (2013). Menjadi guru professional. Jakarta: Esensi Erlangga Group. 
Widyaningsih, S. W., \& Yusuf, I. (2015). Penerpan Pembelajaran Listrik Dinamis Model Kooperatif Tipe STAD Menggunakan Pendekatan Dengan Integrasi Nolai- Nilai Karakter Terhadap Aktivitas dan Hasil Belajar Peserta Didik. Pancaran Pendidikan.

Widyaningsih, S. W., \& Yusuf, I. (2015). Penerapan Pembelajaran Listrik Dinamis Model Kooperatif Tipe Stad Menggunakan Pendekatan Ctldengan Integrasi Nilai-Nilai Karakter Terhadap Aktivitas Dan Hasil Belajar Peserta Didik. Pancaran Pendidikan, $4(2), 223-234$.

Yamin, M. (2013). Strategi dan metode dalam model pembelajaran. Jakarta: GP Press Group. 